\title{
DEMOKRATI OG JØDISK FUNDAMENTALISME I ISRAEL
}

\author{
Peter Steensgaard Paludan
}

\begin{abstract}
Introduktion
Israel er på den ene side en moderne stat, højt industrialiseret, med en moderne undervisningssektor, et fungerende demokratisk system og med en befolkning, der for flertallets vedkommende er præget af moderne værdier. Fx tages den moderne naturvidenskabs sandhedsværdi for givet, historien opfattes som en immanent årsagsvirkningssammenhæng, og normerne for det sociale liv ses som noget, der bestandig modificeres i en vedvarende koncensussøgende debat, selv om mangt og meget i det normative felt hidrører fra jødisk historie og tidligere har haft en klar transcendental forankring. Men samtidig findes der, i den mest traditionalistiske ende af det religiøse (og religio-politiske) spektrum grupper på tilsammen nu ca. 6\% (Berman 1998, 10), der repræsenterer præmoderne opfattelser og adfærdsformer og gør denne holdning gældende i et programmatisk opgør med de kulturelle aspekter af moderniteten. Ikke med dens teknik og medicin; de ved, at megen teknik bygger på naturvidenskabelige resultater, men den naturvidenskabelige teoridannelse forkastes så snart den kommer i konflikt med den religiøse tradition, f.eks. den bibelske skabelsesberetning. Almindeligvis kaldes denne del af befolkningen ultra-ortodokse eller haredim (hebr. "de som frygter [Herren]”). De er fundamentalister defineret som en gruppe, der kræver ubetinget troskab med den autoritative religiøse tradition både med hensyn til de religiøse ideer og den i traditionen foreskrevne adfærd, uden afkortelser/selektion og uden nyfortolkninger, der søger at tilpasse traditionen til den forkastede modernitet, og de ser traditionelt jødisk liv i det præmoderne Østeuropa og i Mellemøsten-Nordafrika som en religiøs guldalder. Den form for fundamentalisme, de repræsenterer, er karakteristisk ved, at de søger at genskabe denne (idealiserede) fortid som en modkultur, realiseret i deres egen enklave, hvor de i det daglige isolerer sig fra det moderne israelske samfund og opbygger barrierer, der skal sikre mod kulturel indflydelse fra dette, samtidig med at de kræver indflydelse på det israelske samfund. ${ }^{1}$ Deres påstand om en umiddelbar kontinuitet med de traditionelle jødiske samfund er i øvrigt en konstruktion: Konfrontationen med moderniteten har medført ændringer i den interne institutions- og familiestruktur, givet den rabbinske ledelse en autoritet, der går langt ud over den respekt, man traditionelt nærede overfor eksperterne i den religiøse tradition, og har gjort dem væsentligt strengere og mere restriktive i deres tolkning af den autoritative tradition end tilfældet var for 150 år siden (Friedman 1986; 1987; 1991, 56-58, 70-87), Paludan 1995, 4-7 og Sharot 1992, 32).
\end{abstract}

\footnotetext{
${ }^{1}$ Jeg anvender her fundamentalismedefinitionen hos Sharot (1992, 25, 31, 35 og 39) sammenholdt med Heilman \& Friedman (1991, 254-58).
} 
I det følgende vil jeg undersøge, hvad haredim opfatter som legitim magtanvendelse, hvorledes denne opfattelse og den deraf følgende politiske praksis kommer i konflikt med Israels demokratiske samfundsordning, hvad der er deres magtbasis, og hvad årsagen er til, at de har kunnet gøre sig politisk gældende med større styrke, end man skulle forvente ud fra deres andel af befolkningen.

\section{Traditionel og moderne magtopfattelse}

De første årtier af statens historie brugte haredim først og fremmest den begrænsede politiske magt, de havde gennem deres politiske partier, til at sikre deres minoritetsrettigheder - retten til eget uddannelsesvæsen og andre særlige institutioner i deres egen sektor - men efterhånden (specielt efter systemskiftet i 1977) gør de deres indflydelse mere og mere gældende med henblik på, at den religiøse tradition kan komme til at præge den offentlige sfære i landet enten ved ny lovgivning eller ved en strengere administrativ praksis i implementeringen af, hvad der allerede eksisterer af religiøst inspirerede love (ægteskabs- og skilsmisseret, helligdagslovgivning m.v.). Der er i dag to haredi partier: Det ene er Det forenede Torah-jødedoms Parti (UTJ), der er en sammenslutning af det hasidisk dominerede Agudat Israel og det "litauisk"” dominerede Degel HaTorah. Hver af disse fraktioner har over politikerne et åndeligt råd, Moetset Gedoley HaTorah, ${ }^{3}$ "Rådet af dem, der er store i Torah'en”, der afgør hovedlinierne i deres politik og høres før alle større afgørelser. Det har i øjeblikket 5 mandater i Knesset. UTJ er overvejende ashkenazisk og har generelt fået relativt få stemmer uden for haredim's egen kreds - en undtagelse var dog valget i 1988. Agudat Israel har som talerør dagbladet HaModia, Degel HaTorah tilsvarende sit Yated Neeman.

Sefardiske Torah Vogtere (Shas) er et moderat sefardisk haredi parti, der henter sine stemmer fra vælgere med oprindelse i den islamiske verden, mange fra Nordafrika. Nogle af disse indvandrere sendte deres børn i ashkenaziske (oftest "litauiske”) haredi skoler, hvis holdninger påvirkede dem. Mange af Shas’ ledere er tidligere studerende i ashkenaziske haredi yeshivah'er, men trods dette har partiet i mangt og meget bevaret sefardisk tradition for moderation og større tolerance overfor anderledestænkende (Stillman 1995, 76ff; Heilman \& Friedman 1991, 244-51 og Friedman 1991, 175-85).

\footnotetext{
${ }^{2}$ Dvs. tilhængere af den form for ultra-ortodoksi, der udviklede sig i Litauen (og Polen) blandt efterkommerne af de såkaldte mitnaggedim (modstanderne af hasidismen), hvis liv centreredes omkring yeshivah'erne.

3 “De store" (herefter gedolim) er de hasidiske gruppers ledere (rebber) og de ledende eksperter i den religiøse tradition, først og fremmest lederne af de mest prestigefulde yeshivah'er. Lydighed mod gedolim anses for at være en pligt. Når vigtige spørgsmål presser sig på, offentliggør de en Daat Torah, et "Torah synspunkt”, en teknisk betegnelse for gedolims afgørelse om, hvad der er Torah'ens mening om en bestemt problemstilling, eller hvordan man skal forholde sig i en bestemt type situationer, og et sådant anses for bindende for den pågældende gruppe. Det “litauiske” Degel HaTorah var oprindelig en udbrydergruppe fra Agudat Israel under ledelse af Rabbi Eliezer Menahem Man Shakh, leder af Ponevez yeshivah’en i Bene Berak, men for ca. 5 år siden måtte R. Shakh, der i dag nærmer sig de 105 år, overlade ledelsen af partiet til yngre kræfter. Hvert af de to partier har bevaret egen organisation, selvom de har sluttet sig sammen igen p.g.a. frygten for spærregrænsen (1,5\%).
} 
De dannede deres eget parti, der første gang opstillede ved et valg til Knesset i 1984, fordi de mente, at den ashkenaziske haredi verden diskriminerede dem. Til forskel fra UTJ henter de de fleste af deres stemmer blandt sefardere, der er traditionelle, men hverken er ultra-ortodokse eller tilhængere af en form for modificeret, moderne ortodoksi. Ved sidste valg fik Shas 17 mandater (ud af Knessets 120), og af disse kan næppe mere end de 3 være vundet på sefardiske haredi stemmer. Hvilke befolkningsgrupper det er, der på denne måde er med til at give dem magt, vil vi vende tilbage til.

Haredi partierne har i mange henseender kunnet samarbejde med Det nationalreligiøse Parti (NRP), der indtil 1984 var det største religiøse parti, men som nu kun råder over 5 mandater. Partiet er moderne ortodokst og søger at udligne spændingen mellem religiøs tradition og det moderne samfund, inklusive dets demokratiske karakter (Liebman 1997, 37-55). I de seneste to årtier har stærke kræfter inden for partiet dog bevæget sig i retning af en mere markant ortodoks position (Liebman 1993, 140). Nærværende artikel koncentrerer sig imidlertid om haredim.

Bortset fra evnen til at tiltrække ikke-haredi vælgere er partistrukturen med til at give haredim en indflydelse, der rækker ud over deres andel af befolkningen. Så længe de to store partier, Arbejderpartiet og Likud ikke kan enes om regeringssamarbejde (og det hindrer ikke mindst fredsprocessen dem i) er haredi partiernes tilslutning nødvendig for begge disse partier for at kunne danne regering. Det er ikke overvældende, hvad de ad den vej har opnået med hensyn til at sætte et religiøst præg på det israelske samfund - de store partier har ikke uden held forsøgt at spise dem af med løfter om (store) øgede bevillinger til haredi institutioner; men resultater har de dog haft, såsom at det nationale flyselskab El-Al siden 1982 ikke har måttet flyve på Sabbatter og andre helligdage (andre israelske selskaber udvidede deres flyvninger), at abortloven blev strammet, og at import af ikke-kosher kødprodukter blev forbudt. ${ }^{4}$ Legitimeringen af denne form for anvendelse af religiøs magt sker med henvisning til et talmudisk princip, der siger, at alle i Israel er garanter for hinanden, forstået sådan, at enhver er ansvarlig ikke blot for, at hans egen adfærd er i overensstemmelse med den af traditionen foreskrevne, men også for at andres er det. Der er således tale om et princip, hvis implikationer er i oplagt modstrid med pluralisme og demokrati, idet det kan bruges til at træde centrale demokratiske minoritetsrettigheder under fode. Individuel synd forestiller man sig ikke, at man kan hindre. Hvad folk gør i det private, kan man kun øve indflydelse på ved at formane og forsøge at overbevise. Derimod kan man hindre, at de offentlige ordninger har en syndig karakter, nemlig ved ikke at være i overensstemmelse med halakhahens (den traditionelle religiøse lovs) forskrifter, f.eks. ved at være brud på forskrifterne om sabbatshvile, tillade ægteskaber, der udelukkes af halakhahen, eller ved at give ligestilling af reformjødedom med ortodoksi, tillade aborter på social indikation osv. Rabbi Shakh, leder af de "litauiske" haredim, udtrykker det på den måde, at en jøde et eller andet sted i verden, der arbejder på Sabbatten, måske kan have en undskyldning. Han kan ikke arbejde om søndagen p.g.a. den pågældende stats helligdagslovgivning, og det

${ }^{4}$ Sharkansky taler om, at der i kampen mellem ortodokse og sekulære er "tied score, more or less” (1996, 142). Nedenfor vil det dog fremgå, at udviklingen, trods svære kampe, har ført i en sekulariserende retning. 
kan være, at han ikke kan forsørge sin familie, hvis han også helt skal undlade arbejde på Sabbatten. Men i en stat, hvis flertal er jøder, er der ingen undskyldning. Der kan og skal man indrette ordningerne sådan, at kun strengt nødvendigt arbejde må udføres (hospitaler, politi osv.) på Sabbatter og fester, og selvfølgelig indrette det sådan, at ingen kommer i nød af det (Mikh. I, 36; Paludan 1995, 12ff).

Jeg kan illustrere synspunktet kort ved en situation fra midten af februar i år. Israel har, p.g.a. de religiøse partiers krav, ikke noget borgerligt ægteskab. Vielser og skilsmisser administreres for jøders vedkommende af rabbinske domstole, for muslimers af deres sharia domstole, for kristnes af deres respektive præsteskaber. Det betyder, at blandede ægteskaber er umulige - bortset fra ad visse omveje såsom at tage turen til Cypern og blive viet borgerligt dér, hvilket så anerkendes i Israel som gyldigt ægteskab. Nu vil indenrigsministeriet imidlertid acceptere, at fremmede konsulater foretager vielser under forudsætning af, at den ene part har borgerskab i det land, konsulatet repræsenterer, også i tilfælde, hvor den pågældende har dobbelt statsborgerskab, f.eks. både russisk og israelsk - altså en lille åbning. Det vil hjælpe bl.a. russisk-jødiske immigranter, som er i klemme, fordi de er indvandrede som jøder og af den grund har fået statsborgerskab, men efter en definition af begrebet jøde, der ikke er i overensstemmelse med overrabbinatets, så dette ikke vil vie dem. Avraham Ravits, en af lederne af UTJ's Degel HaTorah fraktion, kommenterede:

Being a Jew isn't about personal decisions and individual morality. It's about Halacha. Sometimes I don't understand the laws either ... Even if we do not understand, we do know that Jewish law was given to us by the Holy One, blessed be He, and we must obey. And that is binding on all of us, even those who call themselves secular (Jerusalem Post 18/2-00).

Problemet er altså for Ravits og andre haredim, at der er tale om en jødisk stat, og alle jøder er, hvad enten de vil det eller ej, forpligtet på halakhahen, og derfor er det legitimt, at de religiøse bruger, hvad de end måtte have af magt (f.eks. p.g.a. partistrukturen) til at forsøge at præge den offentlige sfære i overensstemmelse med halakhahen. Og problemet bliver endnu mere påtrængende af, at denne jødiske stat ligger netop i det hellige land, der qua helligt både fascinerer og indgyder frygt. Det hellige land adskiller sig fra andre lande ved at have den særlige egenskab, at det udspyr syndere (3 Mos 18,28). ${ }^{5}$ Hvis man dér ikke overholder halakhahen, vil den guddommelige straf - der rammer kollektivet - ramme særligt hårdt. R. Shakh var ikke i tvivl om, at når Saddam Hussains raketter ramte Israel under Golfkrigen i 1991, var grunden i sidste instans ignoreringen af Torahen og de mange brud på sabbatshvilen i Israel. ${ }^{6}$

\footnotetext{
${ }^{5}$ R. Shakh henviser hyppigt til dette sted, se f.eks Mikh. I, 13; 15-17; III 142-44.

${ }^{6}$ BeZot. 95-99. YN 13/11-98 anvendte disse udtalelser af R. Shakh under den ny Irak-krise i efteråret 1998 og refererede ligeledes hertil i forbindelse med kamphandlinger i Sydlibanon 30/11-98. Den deuteronomistiske historietolkning, der kommer til udtryk disse steder, bruges generelt som tolkningsmønster for Israels udenrigspolitiske problemer af både R. Shakh selv og YN.
} 
Konsekvensen af, at de religiøse partier presser på for lovgivning baseret på den religiøse tradition, og at de store sekulære partier i et vist omfang (begrænset af hensynet til deres vælgere) har været villige til at give dem indrømmelser for at få deres støtte til gennemførsel af vigtige dele i deres programmer, er, at der er gennemført og opretholdes ordninger, som flertallet opfatter som "religiøs tvang”.

Bag haredim’s holdning ligger et traditionelt magtbegreb, der gøres gældende på trods af de radikalt ændrede betingelser i en moderne stat. I det traditionelle samfund var der en i det mindste vidtstrakt konsensus om normerne, men det var ikke den, der gav dem deres gyldighed. De stod fast, fordi de var forankrede i en transcendent autoritet, som man som en selvfølgelighed underordnede sig. Derfor var det legitimt at anvende tvang mod afvigere, også når der var tale om moralsk eller rituel afvigelse (grov offentligt begået synd) eller afvigende meninger, og rabbinerne havde visse magtmidler hertil, f.eks. forskellige grader af ekskommunikation. I moderniteten flytter normernes gyldighedsgrund derimod fra den transcendentale kilde til selve den sociale konsensus, der altid er noget uafsluttet (den kan ikke etablere endegyldige normer), dvs. den fri samtale er forudsætningen. Konsekvensen for magtbegrebet bliver, at legitim magt i moderniteten er hvad Habermas har kaldt "herredømmefri kommunikation”.

Mange moderne ortodokse tænkere har reflekteret over disse problemer og mere eller mindre konsekvent draget konsekvenserne for deres teologi og dens politiske implikationer. Således kunne Rabbi Rafael Aron Ben Simon, en respekteret halakhisk autoritet, født i Marokko i 1847 og Cairos overrabbiner fra 1881 til 1921, ikke blot lægge en moderat kurs i sin fortolkning af, hvordan de enkelte bud skulle praktiseres under de kraftige forvandlinger, der fandt sted i hans tid i Ægypten, inklusive dets jødiske samfund. Men det stod ham klart, at der var tale om så dybtgående ændringer af livsvilkårerne, at religiøs nytænkning var påkrævet. Den nye udvikling introducerede under vestlig påvirkning en hidtil uset grad af individuel frihed. Under de omstændigheder måtte de rabbinske autoriteter slet og ret lade deres magtmidler falde, et afkald, der vel at mærke ikke var dem pålagt af den ikke-jødiske øvrighed.

It was unheard of in any previous time that the governing authorities would loosen restraint so that an individual would be free in his religion and belief to a point that no one can say to him, "What does thou?" No one has the authority to chastise a person who commits a religious transgression, even if it is committed in public. This is the result of the freedom and liberty prevailing in the land (Citeret efter Stillman 1995, 39).

Rabbi Haim Hirschensohn, født i Safed i Galilæa i 1857 var en af de relativt få, der på en dybtgående og ekstensiv måde analyserede spørgsmålet, om det var muligt på basis af traditionel jødisk religiøs lov (halakhah) at opbygge en moderne, demokratisk stat,

\footnotetext{
${ }^{7}$ Se f.eks. Habermas (1982, 64). Det kritiske potentiale i denne kategori er oplagt, men den har ikke desto mindre også en væsentlig deskriptiv værdi, dels fordi den herredømmefri kommunikation eksisterer, selv om den ofte nok sættes ud af kraft af interessepolitik m.v., dels fordi sådanne kategorier er medbestemmende for, hvilke spørgsmål der rettes til materialet.
} 
med moderne økonomi, social organisation og kulturliv. Han bekræftede dette i sit omfattende teologisk-politiske forfatterskab (Schweid 1994). Denne linie videreføres af andre, f.eks. Rabbi Sol Roth (1988) og af det moderat ortodokse parti Meimad, der dannedes i 1988 i protest mod NRP's højredrejning. ${ }^{8}$

Det karakteristiske for haredim som fundamentalister er imidlertid, at de konsekvent afviser at give køb til moderniteten. Derfor kan deres påstand være, at selv om en konsensus om de traditionelle normer ikke mere findes, så påhviler det ikke desto mindre alle jøder at indordne sig under dem, fordi de er gudgivne, og derfor er det legitimt at anvende "religiøs tvang”, 9 f.eks. ved kun at have religiøse (dvs. ortodokse) ægteskabsog skilsmisseinstitutioner.

\section{Haredim og demokrati}

Der er en mærkbar forskel på, hvordan temaet demokrati behandles af haredi repræsentanter i Knesset og af de to haredi dagblade, og hvordan det behandles i ledernes bøger, som man ved, stort set kun læses internt af haredi befolkningen. R. Shakh gør således sit syn på demokratiet klart i en række breve, trykt i samlingen Mikhtavim UMaamarim, ${ }^{10}$ og her er afvisningen af denne styreform kategorisk: demokrati betegnes som en [guld]kalv, trefe (urent), en katastrofe, ødelæggelse af menneskeheden, en forbandelse og en kræftsygdom. At gøre Israel til et "demokratisk folk” er at forsøge at gøre det til noget andet end det, der religiøst set ligger i begrebet "Israels folk”; det betyder at gøre det til "et folk som alle folkeslagene”, som han formulerer det med profeten Ezekiels fordømmende udtryk (Ez 20,32). Israel er "en stat, der er bygget på [sekulær] lov, og ikke på halakhah” (Mikh. I, 6f; 22f). Dens love er love, man opfinder ud fra sig selv, eller som man overtager fra andre folk - i begge tilfælde menneskeopfundne, til forskel fra Torahens gudgivne love. Forskellen drejer sig ikke bare om de enkelte love, Knesset vedtager, selv om R. Shakh opregner en række eksempler på love, der indholdsmæssigt strider imod Torahen, men er en forskel mellem to systemer. For demokratiet er den individuelle valgfrihed i centrum; den enkelte ønsker så vidt muligt at

\footnotetext{
${ }^{8}$ Se partiets platform, http://www.meimad.org.il (hebr. og eng.). Navnet er akronym for: ”Jødisk stat, demokratisk stat”. Partiet repræsenteres i Knesset af én person, rabbiner Michael Melchior. Det er tvivlsomt, om Meimad havde opnået dette ene mandat, hvis partiet ikke var indgået som del af Ehud Baraks samlingsparti, Israel Ahat, der består af Arbejderpartiet, Meimad og et mindre sefardisk parti.

${ }^{9}$ Liebman (1997, 78f) afviser det sekulære slagord “religiøs tvang” og mener, at man snarere bør tale om love, der kan have skadelige virkninger for bestemte grupper eller hele samfundet, eller love, f.eks. forbudet mod rutebusser på Sabbatter, som medfører ”inconveniencies”. Han forbigår imidlertid ægteskabs- og skilsmisseordningen.

${ }^{10}$ Mikh.V, nr. 521-525, s. 121-27. Det flg. refererer specielt til dette afsnit hos R. Shakh. Tre af overskrifterne lyder: "Man må ikke stole på det nuværende regimes politiske beslutninger, for hele dets sigte er, at dette skal være en fri demokratisk stat” (nr. 521). ”Demokratiet er trefe [urent], og hele formålet med det er at rive Israels folks vej op med rode” (nr. 523). ”Demokratiet ødelægger menneskeheden; Torahens grundlov giver livets lykke i eje” (nr. 525).
} 
være ubegrænset. Men det fører til tøjlesløshed og anarki. ${ }^{11}$ Det viser sig bl.a. ved, at vælgerne ikke stemmer efter, og de valgte repræsentanter ikke træffer beslutninger efter, hvad de er overbevist om er til bedste for samfundet som helhed, men ud fra snævre egoistiske interesser. Ad den vej kan man ikke skabe lykke, og den forståelse af frihed, der ligger bag, er heller ikke sand frihed, men betyder at være i sit begærs og sine lidenskabers vold. Kun den, der vælger at underkaste sig Torahen hæves herover og opnår sand frihed. Alene Gud kender menneskets natur til bunds, og derfor er det kun ham, der kan sætte de rette grænser for det; han ved, hvad det kan bære, og hvad det ikke kan bære. De menneskeskabte "systemer”, som ikke kan hvile på dette grundlag, da mennesket ikke kender og ikke kan kende sin natur til bunds, må således føre til ulykke. Det gør demokratiet ved dets anarkistiske tendens, og det gjorde kommunismen ved at gennemføre lighedsprincippet så konsekvent, at det udelukkede privateje. Fordi det var i modstrid med menneskets natur, kunne det kun gennemføres ved vold. Skaberen har derimod givet mennesket en lov, der svarer til dets natur og bringer det lykke. ${ }^{12}$

En lignende tankegang finder vi hos den egyptiske, muslimske fundamentalist Sayyid Qutb (1978, 161-72). Gud, som har skabt universet, har fastsat love for det, som betyder, at alt fungerer harmonisk. Også mennesket i dets legemlighed følger "ufrivilligt” de af Gud fastsatte naturlove. For dets viljeshandlinger har Gud imidlertid foreskrevet sharia, der er en del af den universelle lov og er i overensstemmelse med den natur, han har givet mennesket. At underkaste sig sharia betyder derfor, at mennesket kommer i harmoni med universet, sig selv og sine medmennesker:

Indeed, the Shari'ah of God harmonizes the external behaviour of man with his internal nature in an easy way. When a man makes peace with his own nature, peace and coorporation among individuals follow automatically, as they all live together under one system, which is part of the general system of the universe (Qutb 1978, 167).

Denne harmoni giver fred i sindet, og den har en velsignelsesbringende virkning på det menneskelige liv; med R. Shakhs udtryk: den bringer lykke. Mennesket selv kan derimod ikke forstå alle universets love og dettes enhed og er derfor ude af stand til at udkaste love, der kan medføre denne harmoni. Den vindes kun i underkastelsen under Guds egen lov. Sharia'en er således total: Den omfatter alle love og regler, der er nødvendige for et menneskeligt samfund. Underkastelsen indebærer altså en anerkendelse af, at kun Gud - ikke mennesker - kan være legitim lovgiver, og det skaber lighed. Ingen har ret til at opkaste sig til lovgiver over andre (Qutb 1978, 88). Underkastelsen medfø-

\footnotetext{
${ }^{11}$ Ikke blot det demokratiske frihedsbegreb, med også lighedstanken sættes under kritik: ”Statsministeren [Rabin] regerer ved hjælp af en eller to stemmer, deriblandt nogle arabiske Knessetmedlemmer. ... Er det efter deres mening en vision for Staten Israel, var det mon det, jøderne ventede på ...?” (Mikh.V, 126).

${ }^{12}$ Se f.eks. Mikh.V, s. 126f: ”Hvor lykkelige er vi ikke i sammenligning med dem [de sekulære], fordi vi har Torahen ... Hvorfor føler de ikke den lykke, der er i den? Fordi de ikke studerer. For hvis de studerede Torah, ville de forstå, i hvor høj grad budene giver lykke til mennesket. Sabbatten var altid den største lykke for en jøde, og de ville give hele verden for den. Torahen lærer menneskene, hvordan man skal leve lykkelige liv.”
} 
rer endvidere frihed: Den frigør fra trældom under andre og fra begær og skaber evnen til at udstå modgang og forfølgelse (op.cit., 103, 183ff, 246, 284ff). ${ }^{13}$

I forbindelse med sin demokrati-kritik kan R. Shakh, uden at forklare det nærmere, erklære, at “... den hellige Torah er det sande demokrati” (Mikh.V, 127). Det kan hænge sammen med tanken om, at det er i lydigheden mod Torahen, den sande frihed vindes; det kunne dog også være et udtryk for, at Torahen styrer Israels folk på en måde, der er i overensstemmelse med dets bestemmelse, og i den forstand er den det sande “folkestyre”. Under alle omstændigheder er bemærkningen apologetisk og afspejler en bevidsthed om, at demokratiet er et populært fænomen i Israel, og at hans tilhængere er eller kan være påvirkede heraf.

Det fremgår også af de omtalte breve, at R. Shakh anser kritikken af de ortodokse partiers politik for at medføre "religiøs tvang” for at være meningsløs: Torahen påtvinger ikke mennesket pligter, men idet den forpligter dem, skænker den dem den sande frihed (Mikh.V, 126). Lejlighedsvis kommer denne opfattelse af frihedsbegrebet til orde i haredi pressen (således YNE 6/5-99), men ikke som led i forsøg på en gendrivelse af de sekulæres anklage for "religiøs tvang”. Her foretrækker de at vende sagen om og gå til modangreb og anklage de sekulære selv, og særlig Højesteret, for at være udemokratisk - et punkt, vi skal vende tilbage til - og for at udøve anti-religiøs tvang.

Trods lighederne mellem Qutb og R. Shakh er der den afgørende forskel, at mens Qutb mener, at teokratiet kan og skal gennemføres i nutiden, om nødvendigt ved jihad mod det herskende afguderiske (jahili) regime, så er R. Shakhs og hans tilhængeres krav mere relative. De er for det første tilbøjelige til at se det fuldkomne teokrati som en tilstand, der først vil komme i den messianske tid, og for det andet ser de positive muligheder i det eksisterende israelske demokrati (YN 12/1-99), så længe det ikke fuldt ud bliver et konstitutionelt, liberalt demokrati. Det kan ikke blot bruges til at sikre haredim's rettigheder, men også til ad parlamentarisk vej at realisere i det mindste et vist omfang af religiøst baserede ordninger, og det kan således opfattes som det for nutiden "mindste onde", indtil forløseren kommer og erstatter det med det fuldkomne herredømme, behersket af Torahen (YN 12/2-99).

Det er oplagt, at disse synspunkter må komme særligt markant til udtryk i forbindelse med grundlovsdiskussionen i Israel. I diskussionerne herom forud for og umiddelbart efter statens oprettelse i 1948 var haredim ikke principielt afvisende, først og fremmest fordi en grundlov ville være en sikring af deres minoritetsrettigheder (Goldberg 1998, 213ff). Men efterhånden som det kom til at stå klart, at selv om kun en minoritet støttede en adskillelse af religion og stat, ${ }^{14}$ ville sekulære, liberale ideer komme til at domine-

\footnotetext{
${ }^{13}$ Sml. Ajatollah Chomeini: Alle menneskeskabte politiske systemer er af væsen tyranniske. Mennesker usurperer sig retten til at lovgive, der alene tilkommer Allah. Konger eller demokratiske flertal påtvinger andre deres love, mens i den islamiske stat alle, regering og folk, er underkastet de af den eneste legitime lovgiver, Allah, fastsatte love. Det er ved at underkaste sig under dem, mennesket kommer fri af sine egoistiske begæringer (1983, 51f og 47f).

${ }^{14} \mathrm{I} \mathrm{kraft}$ af den traditionelle opfattelse, at meningen med mange af de religiøse forskrifter er, at de skal tjene som samfundsmæssig lov, afvises en sådan adskillelse. Det var, hævder Yisrael Spiegel i YNE 30/4-99, 20, en krigserklæring mod selve essensen i det jødiske folks sjæl, da den anden zionistiske verdenskongres (1898)
} 
re den påtænkte grundlov, og man skiftede til en afvisende holdning. ${ }^{15}$ Formanden for Knessets udvalg for "grundlov, lov og juridiske anliggender” formulerede den skepsis, der fandtes i den ortodokse lejr, både hos ortodokse zionister og hos haredim, over for grundlovstanken, på følgende måde:

The main point of the question is the Religious Bloc's fear of the Constitution that we will approve. Because without a Constitution you can always make particular [dvs. religiøse] demands, whether they be or not be fulfilled. In view, however, of the ratio of power in the Knesset and in the country, the Religious Bloc fears that the Constitution will be a secular one. (Citeret efter Zucker 1973, 67).

Mod afslutningen af grundlovsdebatten i 1950 vendte både de ortodokse zionister og haredim sig imod tanken om en grundlov. De ortodokse zionister kunne dog støtte det kompromisforslag, der sluttelig blev vedtaget: at udforme såkaldte basis-love, dvs. de enkelte kapitler af en grundlov, i en gradvis proces, for så ved dennes afslutning at sammenstille dem til en samlet grundlov under tilføjelse af den særlige procedure, der skulle være påkrævet for at ændre den.

Haredim afviste imidlertid også dette kompromis. Og de har fastholdt såvel deres grundlovsskepsis som deres afvisning af basis-love med et liberalt indhold siden, fordi disse kunne true den eksisterende "status quo”, dvs. balancen mellem sekulært og religiøst i den offentlige sfære, og hindre en fremtidig, religiøst baseret lovgivning.

Jeg har i en tidligere artikel behandlet det "litauiske”, af R. Shakh og hans efterfølgere dominerede dagblad Yated Neemans omfattende behandling af problemet gennem 1994, der helt svarer til ovenstående beskrivelse (Paludan 1995, 12-16). Med Netanyahus regeringsovertagelse i 1996 bremsedes den konstitutionelle proces effektivt p.g.a. de religiøse partiers styrke inden for den regerende koalition. Baraks valgsejr i 1999 fik derimod grundlovsdebatten til at blusse op igen, og flere partier, først og fremmest det liberale Centerparti, det venstreorienterede Merets og det markant anti-ortodokse centrumsparti Shinuy, krævede, at den nye regering skulle arbejde målbevidst for at få den konstitutionelle proces ført til ende. Baraks koalition kom imidlertid til at inkludere tre ortodokse partier: Det nationalreligiøse (NRP) og de to haredi partier, Shas og - i de første måneder af den nye regerings periode - UTJ. NRPs og Shas’ deltagelse gjorde forhåbninger om nye skridt på vejen mod en fuldstændig grundlov illusoriske. ${ }^{16}$ Shas

erklærede, at religion er en privatsag og ikke har noget at gøre med den jødiske offentlighed (”the Jewish public body”).

${ }^{15}$ En haredi repræsentant udtrykte denne holdning sådan: ”Any constitution created by man can have no place in Israel.”; citeret efter Zucker 1973, 67. Sml. Avraham Ravits’ begrundelse for Degel HaTorahs afvisning af den i 1992 vedtagne basis-lov ("Menneskeværd og frihed”) ”... we, the religious Jews, have a constitution, that is the Torah constitution” (Goldberg 1998, 226). Ravits bygger her på R. Shakh; se citatet fra YN i Paludan 1995, 16. Vedtagelse af en sekulær grundlov opfattes tydeligvis som en proklamation af, at staten forkaster Torahen.

${ }^{16}$ De to partier udtrådte af regeringen i juli 2000 forud for Camp David topmødet i protest mod Baraks villighed til indrømmelser over for palæstinenserne. 
har formuleret sit syn på den tilspidsede måde, at selv hvis nogen søgte at gøre De Ti Bud til grundlov for Israel, ville man modsætte sig det af frygt for den fortolkning, Нøjesteret som forfatningsdomstol ville give dem (Haarets 26/5-99).

Ikke sjældent giver repræsentanter for haredi partierne udtryk for, at deres endelige mål er en halakhah stat. Således kan Avraham Ravits (UTJ) sige, at

Ifølge min verdensanskuelse er vi ikke kommet her for at oprette endnu et eller andet misfoster af en stat i det semitiske område. Formålet med Staten Israel er først af alt, at det skal være en jødisk stat, baseret på liv i overensstemmelse med Torah og halakhah (Maariv, Musaf Shabbat 11/6-99).

Ligesom den tidligere leder af Shas, Aryeh Deri har givet udtryk for Shas’ længsel efter en sådan halakhah stat (Maariv 9/4-99), kan den nye leder, Eli Yishay, til Jerusalem Post 24/5-99 udtale: "The State of Israel is democratic. Shas and the Council of Torah Sages would like to se an halachic state. If democracy decides in favor of it, this is still democratic, just as if it decided against it.” ${ }^{17}$ Begge partier er imidlertid på det rene med, at det er usandsynligt, den israelske virkelighed taget i betragtning, at der inden for en overskuelig fremtid skulle blive et flertal for med ét slag at indføre en halakhah stat. Det ville også være teologisk problematisk at forestille sig, at en fuldt udfoldet halakhah stat skulle kunne etableres i den førmessianske, ufuldkommenhedens epoke:

We are said to want a theocracy, and this is somewhat true, but that desire is of a purely theoretic nature and does not affect our politics. We firmly maintain, that we are thoroughly in golus, ${ }^{18}$ and that is not our responsibility to end this state through any material means. The only step that we take to end our exile are in studying Torah and keeping Hashem's [Guds] mitzvos [bud]. It is up to Hashem to take whatever political or other steps need to be taken to end our exile when we deserve it and/or when He decides that it is time for Redemption. For our current activities, we are very happy with democracy (YNE 6/5-99).

Mere forbeholdent kan YN 10/2 (jf. 12/2)-99 sige, at når avisen (som vi senere skal se) kritiserer Højesteret for, at det er udemokratisk, at retten afsiger kendelser i spørgsmål, der vedrører religion-stat problematikken, så ligger der ikke heri, at haredim er lykkelige over demokratiet eller overbevist om, at det er en styreform, der er værdig for Israel. Men i det nuværende eksil blandt jøder er den demokratiske ramme det, der mulig-

\footnotetext{
${ }^{17}$ Samme tanke om et parlamentarisk flertals ret til at afskaffe demokratiet og indføre et teokrati (halakhah stat) findes i YN 12/1-99. En undersøgelse, foretaget af Minah Tsemah, viste, at blandt Shas’ vælgere ønskede $55 \%$ en halakhah stat, $41 \%$ et demokratisk Israel. I befolkningen som helhed var tallene: $13 \%$ for en halakhah stat, 83\% for et demokratisk Israel (Yediot Aharonot, HaMusaf LeShabbat, 28/5-99).

${ }^{18}$ Traditionel ashkenazisk udtale af hebr. galut: eksil. Det er et kendemærke for haredim's tænkning, at de anser enhver tilstand forud for messias’ komme, inklusive at leve i en jødisk stat i det hellige land, for at være eksil. Det adskiller haredim fra tendensen blandt nationalreligiøse til at se Staten Israel som i en eller anden, om så nok så afsvækket, forstand ”begyndelsen på forløsningen” (athalta digeula). Jf. Ravitzky 1996, 145-80 og Paludan 1995, 7-12.
} 
gør sameksistensen mellem den sekulære og den religiøse lejr. Og, tilføjes det, kun på grund af den kan haredim bruge den smule indflydelse, de har, til at få, hvad der tilkommer dem. Disse artikler, der kun er eksempler blandt mange, afspejler imidlertid en anden holdning end den, der var karakteristisk for haredi partierne i statens første tre årtier: at det eneste man kunne gøre var at forsvare haredi enklavens rettigheder i en gudløs verden. De er skrevet som led i kampen for at bevare de eksisterende, religiøst inspirerede ordninger i det store samfund og for at holde muligheden åben for at udbygge og forbedre dem. Den iøjnefaldende spænding mellem på den ene side hævdelsen af, at målet for den politiske aktivitet er en halakhah stat, og på den anden side påstanden om, at det fuldkomne teokrati alene hører hjemme i den messianske tid, er ikke en selvmodsigelse, ${ }^{19}$ men indicerer, at haredim forstår deres krav sådan, at det israelske demokrati skal holde muligheden åben for stykvist at tage skridt i retning af en halakhah stat, samtidig med at man bevarer bevidstheden om, at fuldkommenheden ikke indtræder som summen af disse skridt, men kun ved at Gud sender messias. Det gensidige ansvar for, at Torahen opfyldes, forpligter imidlertid haredim til at presse på, for at disse skridt tages. "Det er os pålagt at arbejde for at udvirke, at en regering i Israels land så meget som muligt tager vor hellige Torah i betragtning,” hedder det i en udtalelse fra Agudat Israel's og Degel HaTorah's åndelige råd (YN og Mod. 14/5-99).

Det kun forbeholdne ja til demokrati, denne position kan rumme, betyder, at haredi politikerne må protestere mod krav om, at grundlovsprocessen føres til ende. Avraham Ravits kan formulere det sådan:

Lad os antage, at det lykkedes mig at overbevise Knessets medlemmer om, at der er logik i at fritage yeshivah studenter fra militærtjeneste. Hvis vi befandt os i en situation, hvor der fandtes en grundlov i Israel, hvori - naturligvis - lighedsprincippet var forankret, så ville ingen overtalelse hjælpe mig. Nogen ville indanke sagen for Højesteret, og denne ville forpligte alle yeshivah studenter til at lade sig mobilisere, altsammen i lighedens navn. ${ }^{20}$

Ravits omtaler endvidere, at han faktisk lod sig overtale til at stemme for den i 1992 vedtagne basis-lov "Erhvervsfrihed" med det argument, at den var en fordel for ortodokse, fordi den sikrede mod problemer hidrørende fra, at de ikke ønsker at arbejde på helligdage. Ingen forestillede sig, at loven kunne udnyttes til at legitimere import af

\footnotetext{
${ }^{19}$ Ravitzky mener således, at haredim's nuværende krav om en Torah stat udvisker forskellen mellem nutiden og den utopiske, messianske tid, og dermed underminerer den grundlæggende tanke, at nutiden er eksil blandt jøder og således præget af en ufuldkommenhed, mennesker ikke kan ophæve (Ravitzky 1996, 169). Jeg er ikke stødt på nogen haredi publikation, der eksplicit tager problemet op til behandling.

${ }^{20}$ Haarets 26/5-99. Artiklen indeholder bl.a. et interview med Ravits, som også giver andre eksempler på en liberal grundlovs skadelige virkninger: Det ville blive umuligt at lukke gader for trafik på helligdage, selv i områder med ren haredi befolkning, og selv, hvis man overbeviste de sekulære om berettigelsen. Og i enheder i hæren med kun sekulære soldater ville man i den enkeltes rettigheders navn kunne forlange mad, der ikke var kosher, og krav om en ensartet undervisningsplan for alle skoler mere vidtgående end det nuværende krav om et fælles minimum, ville ikke kunne modstås.
} 
ikke-kosher kød. Men nogen gik til Højesteret og fik medhold i, at dette - med den nye lov - var legitimt. Loven blev derefter ændret. Regeringen Rabin ønskede af hensyn til støtten til fredspolitikken et godt forhold til Shas.

I taler og publikationer, der sigter på et publikum uden for haredi samfundet, undlader deres repræsentanter et frontalt angreb mod demokratiet, sådan som vi fandt det hos R. Shakh. Man nøjes med at tale om det som det mindst onde system for den nuværende tid. Det er ganske vist stort set kun haredim, der holder disse blade, men man er sig bevidst, at der holdes øje med dem, f.eks. på de sekulære bladredaktioner. Haredi pressen kan problematisere en konsekvent anvendelse af visse demokratiske principper, f.eks. lighedsprincippet, eller kritisk hævde, at demokratiet er uden "real substance", dvs. mangler værdier (YNE 30/4-99), men giver det alligevel et forbeholdent ja. De er sig som nævnt bevidst, at de kan få brug for den beskyttelse af minoriteter, som demokratiet giver; og de er klar over, at det israelske demokrati hidtil har givet dem visse fordele i form af økonomisk støtte til haredi samfundet, samt at det har vist sig at være et brugbart instrument til at sætte et vist religiøst præg på den offentlige sfære i Israel. Etablerer det israelske politiske system derimod, gennem en grundlov, basis-love eller en velfungerende forfatningsdomstol sådanne strukturer, som problematiserer videreførelse heraf ved at hindre, hvad de sekulære opfatter som "religiøs tvang”, så overskrides forbeholdet, og kritikken sætter ind. Da de imidlertid ved, at det ville svække deres politiske stilling, hvis de ikke fremstår som demokrater, drejes kritikken sådan, at haredim fremstilles som de rette forsvarere af demokratiet, og de sekulære som dem, der - i anti-religiøs interesse - svækker det.

Haredi politikere og deres presse er ganske følsomme over for anklager om, at de repræsenterer udemokratiske holdninger. Det vakte således vrede blandt Shas' ledere, da den israelske ambassadør i Tyskland i et interview med Die Welt omtalte Shas - og andre religiøse partier - som ikke baserede på demokratiske principper, men “... on godly law, the words of the Rabbis”, og sagde, at repræsentanter for denne opfattelse var første generations indvandrere fra tredjeverdenslande, der ikke er vokset op med demokratiske værdier. Aryeh Deri afviste vredt enhver karakteristik af Shas som udemokratisk. ${ }^{21}$ Det ligger på samme linie, når YN 16/2-99 med tilfredshed mener at kunne notere sig, at den europæiske presse fremstillede den haredi dominerede demonstration 14/2-99 mod Højesteret, som vi nedenfor skal vende tilbage til, uden den brug af sammenligninger mellem haredim og muslimske fundamentalister, som man finder i israelsk presse, og uden påstande om, at haredim skulle være udemokratiske.

For at kunne fremstille sig som demokratiets forsvarere, (om-)definerer man demokrati til blot at betyde flertalsstyre, mens demokrati som en styreform, der bygger på et sæt af værdier (om individets ret til medbestemmelse, tolerance, lighed osv.), sættes under kritik. Intet under, at konfrontationen bliver særlig intens omkring basis-love og Højesterets funktion som forfatningsdomstol. Selv om landet ikke har en fuldt færdig

\footnotetext{
${ }^{21}$ Jerusalem Post 3/2 og 4/2-99. Ambassadøren blev hjemkaldt til reprimande hos den daværende udenrigsminister, Ariel Sharon, og fik ikke forlænget sin tjenesteperiode i Tyskland.
} 
grundlov, har Højesteret etableret sig som forfatningsdomstol på grundlag af de eksisterende basis-love, og efter vedtagelsen i 1992 af de to basis-love: "Erhvervsfrihed” og “Menneskets Værd og Frihed”, er så mange af de emner, der skal indgå i en moderne liberal grundlov, dækket ind af basis-love, så man kan tale om (og bl.a. Højesterets præsident betragter det sådan), at Israel er blevet et konstitutionelt demokrati (Barak 1998). Den situation, Ravits udtrykte frygt for i det ovenfor citerede interview, er altså gennem 90'erne rykket tættere på. Der mangler stadig nogle områder, og der mangler en effektiv sikring af forfatningen; de enkelte basis-love kan ændres ved et flertal på 51\% i Knesset, dvs. 61 mandater. Og haredim modsætter sig energisk både den nødvendige udfyldning og sikring, ligesom de konstant angriber Højesteret for dens, som de udtrykker det, “afgnavning” af statens jødiske karakter ved ud fra demokratiske principper, der indgår i basis-lovene, at underkende love og administrative tiltag, som haredim og de nationalreligiøse har fået igennem, fordi de var nødvendige, for at skiftende regeringer kunne have et flertal i Knesset. Det er "juridisk diktatur", ${ }^{22}$ hævder de, der hindrer, at parlamentariske flertalsbeslutninger føres ud i livet. Hvilket er rigtigt. Essensen i disse højesteretskendelser er en begrænsning af den parlamentariske magt, der kun er legitim på den præmis, at den respekterer de individuelle frihedsrettigheder.

Gennem de sidste måneder af 1998 og de første 8 måneder af 1999 var haredi pressens lederartikler hyppigt optaget af problemerne omkring basis-love og Højesterets funktion som forfatningsdomstol, især i tiden omkring demonstrationen den 14/2. Anledningen til disse artikler har dels været højesteretskendelser, der gik haredims interesser imod. De vigtigste var en kendelse af 9/12-98 om regeringens pligt til, inden for et år, at drage omsorg for en holdbar ordning af problemerne vedrørende indkaldelse af yeshivah studenter til forsvaret, og kendelsen af 19/11-98 om religionsministeriets pligt til at optage repræsentanter for reform- og konservativ jødedom (og ikke bare ortodokse) i de lokale religiøse råd. For haredim er dette et afgørende punkt, fordi de mener, at staten, ved at indoptage reform- og konservative repræsentanter i sådanne officielle råd, anerkender deres tolkning af jødedommen som ligeværdig med de ortodokses, og det samme vil de selv gøre ved at sidde i rådene sammen med dem. Det vil stride mod deres tro, påpeger de. Der foreligger da også fra gedolim en klar instruks om, at dette er utilladeligt. De fremfører derfor - noget anstrengt - denne kendelse som et eksempel på den “anti-religiøse tvang” eller "samvittighedstvang”, som Højesteret efter deres mening søger at udøve mod dem (f.eks. YN 21/11-98, 22/1, 14/2, 24/2-99). ${ }^{23}$ Men også den betydning, grundlovsproblemet fik under valgkampen og i de efterfølgende koalitionsforhandlinger, bidrog til den litterære aktivitet. En af disse ofte meget lange lederartikler begynder således:

De, som forfølger jødedommen i Staten Israel, besluttede for nogle år siden, at det er nødvendigt én gang for alle at sætte en stopper for den demokratiske magt, som de religi-

\footnotetext{
${ }^{22}$ Udtrykket er blevet en fast term i både YN og Mod.

${ }^{23}$ Gennem en mangeårig udvikling med gentagne klager til Højesteret er der efterhånden blevet placeret 10 reform- og konservative repræsentanter i 6 byer, blandt dem Jerusalem, Tel Aviv og Haifa.
} 
øse repræsentanter har i Knesset, som gennem år og med møje har vedtaget nødvendige og minimale love for det jødiske folk, hvad enten det drejer sig om lov til forhindring af salg af svinekød, forbud mod salg af surdejsprodukter under Pesah, overholdelse af Sabbat og [begrænsning af kødimport til] import af kosher kød til landet osv., ${ }^{24}$ love som et flertal af de sekulære ønsker og som de respekterer, og til hvis vedtagelse det var tilstrækkeligt med et almindeligt flertal ved afstemningen i Knesset. ${ }^{25}$

“De, som forfølger jødedommen”26 er især venstrefløjen, der ikke blot opfattes som sådan, fordi den f.eks. finder bevillingerne til haredi institutioner for store og kræver haredim indkaldt til militærtjeneste på lige fod med andre, men også fordi den kæmper imod religiøs lovgivning, som også ikke-religiøse må indordne sig under. Det er forfølgelse af jødedommen netop fordi det af haredim opfattes som en religiøs pligt ikke bare selv at opfylde traditionens forskrifter, men også at drage omsorg for at andre jøder gør det. Venstrefløjen omtales derfor hyppigt i haredi pressen som antijødisk eller sågar som antisemitisk. ${ }^{27}$ Det er for at hindre religiøs lovgivning, hedder det videre, at de har indført og kræver flere basis-love, og Arbejderpartiet og Likud går med på dette, fordi de ikke ønsker at gå direkte imod religiøse love; derfor er basis-love praktiske for dem. De hindrer love med et religiøst indhold ved at gøre det nødvendigt at have mindst 51\% af knessetmedlemmerne bag sig for at kunne introducere sådanne, fordi en eller flere basis-love først skal ændres for at muliggøre dette. Med andre ord, sigtet med basislovene er at begrænse haredims parlamentariske muligheder, og det er, hævdes det, udemokratisk. Desuden betyder basis-lovene, at borgerne kan indanke religiøs lovgivning eller administrative tiltag for Højesteret som forfatningsdomstol. Magten forskydes på udemokratisk vis fra det folkevalgte parlament til en instans, der ikke er valgt, men udnævnt, og som ikke er repræsentativ. Højesteretsdommerne opfatter sig selv som oplyste liberale og træffer deres afgørelser i overensstemmelse hermed, hvilket skader landets jødiske karakter: "Det har vist sig i de senere år, at på trods af, at der i basis-

\footnotetext{
${ }^{24}$ I en opremsning af disse ”minimale” love senere i artiklen nævnes også ægteskabslovgivningen.

${ }^{25}$ YN 23/6-99. Sml. lederen i YNE 3/6-99: Three Attacks on the Religious Community. De tre angreb er kravet om indkaldelse af yeshivah studenter, kravet om udvidelse af det sekulære pensum i haredi skoler og kravet om en grundlov. Det sidste er et angreb på religiøse kredse, fordi det er et forsøg på at begrænse den magt, de har i Knesset; det forrykker magtbalancen fra den politiske scene, hvor de ortodokse har indflydelse, til Højesteret, der skal tolke konstitutionen, og hvor ortodoks indflydelse er tæt på ikke at eksistere. Men det er, fortsættes der, udemokratisk: "The Knesset is the most democratic institution in the State of Israel, and the attempt to transfer power to the High Court is an anti-democratic move."

${ }^{26}$ Betegnelsen ”forfølgelse af jødedommen” eller ”forfølgelse af religionen” dukker hyppigt op i haredi pressen.

${ }^{27}$ Det vakte furore, at Ravits under finanslovsdebatten 4/2-99 efter en skarp kritik af UTJ's krav om ekstrabevillinger til haredi sektoren, kaldte arbejderpartiets Raanan Cohen "din lille antisemit” (Jerusalem Post 5/299). Ravits måtte undskylde, men bemærkningen var næppe blot en fortalelse i en ophidset debat. Brugen af ordet antisemit til karakteristik af haredims modstandere er så hyppig i haredi pressen, at man må formode, at det er almindeligt anvendt på denne måde internt i haredi gruppen. Det vakte ikke mindre opsigt, at Belz hasidernes ugeavis, HaMahaneh HaHaredi (3/12-98) gik så vidt som til at kalde den sekulære israelske elite nazistisk.
} 
lovene står eksplicit, at staten er en demokratisk og jødisk stat, ${ }^{28}$ så forstås ordet "jødisk" af dommerne til vor sorg som et udelukkende symbolsk forhold, og ikke som en retslig værdi eller en værdi, der skal implementeres.” Et andet argument, der ofte anføres mod Højesterets forfatningsretslige kendelser er, at det ikke tilkommer en retsinstans at blande sig i værdispørgsmål og dermed i religiøse anliggender. Samfundets værdier og deres betydning for offentlige ordninger kan alene et folkevalgt parlament tage stilling til. ${ }^{29}$ Skulle Højesteret gå ind i sådanne værdimæssige problemstillinger, ville det kræve, at dens dommere var folkevalgte, og ikke udnævnte personer. ${ }^{30}$

Udover den politiske aktivitet via deres partier søger haredim også at få indflydelse ved at arrangere demonstrationer. De fleste finder sted, når nye cafeer eller andre underholdnings- eller fritidsetablissementer åbner på helligdage, eller når haredim har mistanke om, at arkæologiske udgravninger er stødt på rester af jødiske gravpladser. Den største haredi arrangerede demonstration i statens historie var demonstrationen den 14/2 1999 i Jerusalem, som en protest mod Højesterets forfatningsmæssige kendelser, specielt på baggrund af de to nævnte om reform- og konservative repræsentanter i religiøse råd og indkaldelse af yeshivah studerende. Officielt var det ikke en demonstration, men en "bønne-forsamling”. Man ønskede (og fik) de to overrabbineres deltagelse, og som embedsmænd kan de ikke deltage officielt i demonstrationer, så den forløb som en "bønne-forsamling” med den almindelige eftermiddagsbøn (Minhah) efterfulgt af recitation af Davidssalmer omhandlende synd og nød, tilgivelse og befrielse fra ydre og indre fjender, bønner om Guds barmhjertighed, trosbekendelse (Shema Yisrael) og shofarblæsning. På plakater, løbesedler og på haredi avisernes forsider offentliggjordes en 'Kol Kore ${ }^{, 31}$ fra de to rabbinske råd, der udgør den åndelige ledelse af henholdsvis den hasidiske og den litauiske fraktion af UTJ, med kald til deltagelse i "bønneforsamlingen"/demonstrationen:

Enhvers hjerte må føle smerte og sorg over den åndelige degeneration og over forfølgelsen af religionen og traditionen i vort hellige land. På det seneste er Højesterets åg kommet til at hvile tungt [på os]; det er dens aspiration - måtte Herren forbarme sig - at afklæde Israels folk vor hellige Torah og angribe dets særlige bestemmelse og at påtvinge troende jøder ikke at være lydige mod Daat Torah.

\footnotetext{
${ }^{28}$ Begge principper, at staten er demokratisk og jødisk, omtales i den reviderede basis-lov: ”Knesset” (1985) og i ”Menneskeværd og Frihed” (1992).

${ }^{29}$ Således f.eks. YN 10/2; 12/2; Mod. Tosefet 14/5; YNE 19/2-99: Dommerne repræsenterer udelukkende den sekulære ashkenaziske elite. Som begrundelse for påstanden henvises ofte til, at Højesterets præsident, Aharon Barak, i et af sine skrifter har omtalt meningsdannelsen i den "oplyste offentlighed" som betydningsfuld for det juridiske skøn. Rigtigt er, at den oplyste/højere uddannede del af den israelske befolkning, hvorfra dommerne kommer, stadigt primært er ashkenazisk, og at det er denne del af befolkningen, der har den højeste procentdel af sekulære.

${ }^{30}$ Således de to UTJ repræsentanter Moshe Gafni, generalsekretær for Degel HaTorah i YN 10/2, 4, og Yaakov Litzman, nu medlem af Knesset for Agudat Israel i Mod. 14/5, 5 og Mod.E. 30/4-99, 8-9. Tilsvarende Jonathan Rosenblum, "litauisk" haredi, der er fast columnist for Jerusalem Post (Jerusalem Post 15/6-00).

31 “En stemme, der råber” (Jes 40,3). Således benævner haredim erklæringer eller opråb fra gedolim.
} 
Religionens fundamenter og jødedommens principper er udsat for angreb i form af bespottelse og forhånelse mod Himmelen, reformfolkenes og de konservatives sekt modtager støtte fra myndighederne, så de kan sætte deres klør i alt, hvad der er dyrebart og helligt for os. Den hellige Sabbat er blevet røvet bytte, Israels hellige ting trampes ned, og Torahens og arvens vogtere forfølges på grund af deres tro på og klæben til den hellige Torah og Israels vise (YN 9/2-99).

Derfor kan man ikke tie, men må forsamles for at bede Gud om “... at befri os fra dem, der søger at underminere fundamenterne for religionen og troen."

Kaldet lykkedes. YN hævdede først, at $1 / 4$ million deltog i demonstrationen, men anvendte senere tallet $1 / 2$ million, et tal, der fra begyndelsen af figurerede i Mod. Det var en stor demonstration, om end selv den kvarte million forekom mig overdrevet. ${ }^{32}$ Haredi samfundet har i kraft af sin struktur væsentligt bedre muligheder end andre for at arrangere store demonstrationer. Når gedolim sætter deres autoritet bag gennemførelsen af en demonstration, omtales pligten til deltagelse i alle yeshivah'er, i prædikener i synagogerne, i haredi pressen, på utallige plakater og flyveblade. Og lydighed mod gedolim er en central værdi i haredi samfundet. I øvrigt arrangeres der specialbusser til Jerusalem fra alle haredi bebyggelser i landet til reduceret pris, og haredi aviserne offentliggør, hvornår og hvorfra de afgår. Resultatet er, at de fleste kommer - større skolebørn inklusive, i pæne rækker, anført af deres lærere. Det lykkedes dem imidlertid kun i ringe omfang at mobilisere deltagere uden for deres egen kreds, trods deres ofte fremsatte påstand om, at en stor del af befolkningen støtter dem. Selv nationalreligiøse udgjorde således en beskeden del af deltagerne i forhold til haredim, selv om der i befolkningen er flere af dem. En opinionsundersøgelse viste dog, at 19\% af befolkningen så positivt på demonstrationen, mens mange andre var enige $i$, at der var grund til kritik af retsvæsenet, men ikke i protestens form og intensitet. ${ }^{33}$ Men organisatorerne var tilsyneladende overbeviste om, at demonstrationen ville have effekt. En af dem, fungerende formand for Agudat Israel, Menahem Porush, udtalte til dagbladet Haarets 15/2-99, at "Hvis Højesteret ikke som følge af demonstrationen lader sig overtale med det gode til at ophøre med at blande sig i religion-stat spørgsmål - så vil der blive krig. Den befolkningsgruppe, der var der, er rede til at invadere ethvert sted.” Degel HaTorah's Moshe Gafni var mere afdæmpet og udtrykte sammesteds overbevisningen om, at man ikke ville kunne ignorere så stor en demonstration, men var nødt til at åbne en debat om, hvordan afgørelser om stat og religion træffes.

Årsagen til demonstrationen var som nævnt først og fremmest Højesterets forfatningsretslige kendelser i religion-stat spørgsmål. Manof, Centret for haredi Information, omdelte under demonstrationen en løbeseddel, der opremsede 18 højesteretskendelser inden for det seneste år, hvoraf 17 var gået religiøse interesser imod. ${ }^{34}$ Af dem omtales i

\footnotetext{
${ }^{32}$ Politiet vurderede deltagertallet til 250-300.000, andre skøn var lavere (Yediot Aharonot 15/2-99).

${ }^{33}$ Offentliggjort i Makor Rishon 12/2-99. Almindeligvis antages, at ortodokse af alle slags, haredim, nationalreligiøse og andre moderne ortodokse, udgør ca. 20\% af befolkningen.

${ }^{34}$ Gengivet i engelsk oversættelse YNE 19/2-99, 20.
} 
det citerede opråb kendelsen om inkorporering af reformfolk og konservative i de lokale religiøse råd. Det er også disse to ting, Højesteret og anerkendelse af ikke-ortodokse strømninger som ligeberettigede udtryk for jødedommen, der havde den mest fremtrædende plads i demonstrationens "beslutning" (YN 15/2-99, 2; Mod. 15/2-99, 1). ${ }^{35}$ Derimod er det påfaldende, at hverken opråbet eller "beslutningen” omtaler højesteretskendelsen om indkaldelse af yeshivah studenter. ${ }^{36}$ Lederne har dels holdt sig for øje, at den hidtidige ordning herfor er overordentligt upopulær, ${ }^{37}$ dels har de, og det er formodentlig det vigtigste, ikke ønsket, at demonstrationen skulle ses som et forsøg på at pleje haredims særinteresser. De ønskede den tværtimod forstået som udtryk for deres religiøst betingede ansvar for Israel som helhed. YN understregede, ${ }^{38}$ at det ikke er for deres egen skyld, haredim kæmper og demonstrerer for bevarelse af "status quo" og for muligheden for at forbedre den til religionens fordel. Når reformbevægelsen gennem Højesteret anerkendes som ligeværdig med ortodoksien, truer det ikke haredims tro og livsmønster i deres egen enklave; problemet er, at det er et anslag mod Himmelens ære. Det er det, det handler om. Arbejdsrettens tilladelse til kibbutzer til at holde deres forretninger åbne på helligdage, skader ikke haredim økonomisk, men skader Himmelens ære, og det samme gælder, når Højesteret adopterer moderne værdier (hvilket ikke påvirker haredim) og gør dem normative for det israelske samfund som helhed. Ansvaret for, at Himmelens ære ikke antastes, er samtidig ansvar for Kelal Israel, Israels helhed eller folk. Det store flertal af folket ønsker at bevare deres jødiske identitet. De er troende, og deres tro kommer til udtryk i, at de dog “holder bud, halvvejs-trediedels-kvart.” For dem er haredim garanterne (arevim), der sikrer, at de ikke "fejes med af de skadelige fremmede vinde, der blæser fra rettens haller.” De er vel at mærke garanter, ikke blot gennem overtalelse, men ved at sikre, at samfundet i det mindste er i overensstemmelse med Torahen i det i vor epoke opnåelige omfang ("status quo").

Det resultat, man havde håbet kampagnen og demonstrationen ville få, udeblev imidlertid. Netanyahu synes ganske vist at have lovet haredi partierne at gøre en indsats for at begrænse Højesterets magt (Kol HaIr 8/4; Haarets 12/5-99). Men bortset fra, at Netanyahu formodentlig var klar over, at det var usandsynligt, at han ville kunne få noget sådant gennem Knesset, så kom valget, og regeringen Barak er imod en sådan ændring.

\footnotetext{
${ }^{35}$ Det var også disse to forhold, haredi pressen særligt koncentrerede sig om. ”Beslutningen” fra demonstrationen nævner dog også andre forhold, såsom agitation mod dem, der holder Torahen, brud på sabbatsfreden og udgravninger af jødiske gravpladser. Med sabbatsbrud tænkes der formodentlig ikke blot på, at flere og flere forretninger, caféer, biografer m.v. i de sidste par årtier er blevet åbnet på helligdage, men også mere specielt på en omdiskuteret kendelse 3/12-98 fra distriktsarbejdsretten i Jerusalem om, at en kibbutz uden for Jerusalem kunne have sin forretning åben på helligdage (YN 7/12-98). Omkring 100 forretninger i kibbutzer over hele landet er åbne på helligdage. I det jødiske Jerusalem er i dag ca. 190 caféer, restauranter, kiosker, biografer m.v. åbne.

${ }^{36}$ Den omtales dog i det amerikanske Agudat Israel's støtteerklæring, se Mod.E. 29/1-99, 1.

${ }^{37}$ Ifølge Guttman-rapporten er 90\% af befolkningen imod den (Liebman \& Katz 1997, 23).

${ }^{38}$ Se YN 1/1; 14/1 og 17/2-99. Den sidste findes i forkortet form på engelsk YNE 26/2-99.
} 
Når en højesteretskendelse går religiøse interesser imod, har haredi partierne ofte forsøgt at få gennemført, hvad de kalder en "lov til omgåelse af Højesteret”. Således også i tilfældet med kendelsen om reform- og konservative repræsentanter i de religiøse råd. Den 28/1-99 ændredes loven om religiøse råd med en enkelt stemmes flertal, så den nu kræver, at alle medlemmer underskriver en erklæring om, at de i halakhiske anliggender vil rette sig efter det ortodokse rabbinats instruktioner. De to retninger havde imidlertid intet imod at underskrive; de ville ikke gå mod rabbinatets afgørelser for så vidt disse angik ortodokse institutioner. Men både haredim og nationalreligiøse afviser stadig at sidde i rådene sammen med dem. Resultatet er, at rådene i de pågældende byer er holdt op med at fungere, og sagen er efter nye klager til Højesteret tilbage på dennes bord (Haarets 8/2, 5/5 og 19/5-00).

Det indsnævrede demokratibegreb, vi møder i haredi publikationer, er ikke blot karakteristisk for deres åndelige og politiske ledere, men de synspunkter, der er udbredte i den almindelige haredi befolkning, svarer hertil. Det viser undersøgelser, foretaget af Peres og Yuchtman-Yaar (1998). Det viser sig her, at 64\% af haredi befolkningen mener, at Israel bør forvandles til et teokrati. Alt i alt gav ca. $90 \%$ af haredim udtryk for udemokratiske standpunkter mod $29 \%$ af de ikke-ortodokse.

\section{Haredims magtbase}

1. Haredi enklaven: Styrke og svaghed

Det er klart, at den magt, haredi partierne har, ville være kortvarig, hvis ikke de befolkningsgrupper, der står bag dem, var i stand til at sikre, at deres holdninger blev videreført til den kommende generation. Det har også været deres primære formål, og det er lykkedes. De lever i egne bykvarterer med deres egne institutioner. Opdragelsen støttes af et uddannelsessystem med en lang skoledag og en undervisning, der for størstedelens vedkommende består af religiøse fag. Undervisning i de almindelige skolefag er minimeret og pensum tilrettelagt sådan, at alt, hvad der kunne komme i konflikt med det religiøse univers, udelades. For drengenes vedkommende er der på de øvre trin tale om kostskoler, hvor de unge mænd lever i et totalreligiøst univers. De unge forbliver under religiøs uddannelse henover krise- eller frigørelsesaldrene, puberteten og den alder, hvor man stifter egen familie. Efter at have afsluttet yeshivah uddannelsen i 21 års alderen, bliver de unge mænd gift, hvorefter de fortsætter med studier i den såkaldte kollel, som sagt i korthed er en yeshivah for gifte mænd. ${ }^{39}$ Og dér bliver mange af dem i årevis: $60 \%$ af alle mænd i den arbejdsdygtige alder er under heltids religiøs uddannelse (Berman 1998, 11, 17). Systemet virker, socialiseringen er effektiv; frafaldet er lille ${ }^{40}$ og mere end opvejes af en kraftig naturlig befolkningstilvækst på gennemsnitligt syv børn

\footnotetext{
${ }^{39}$ Uddannelsessystemet er beskrevet i Friedman 1991, 70-79 og Heilman 1992, 168-276.

${ }^{40}$ Haredi uddannelsessystemets effektivitet i denne henseende sættes i relief, hvis man sammenligner med den betydelige sekularisering, der sker blandt tidligere elever i det statslige religiøse (nationalreligiøse) skolesystem. Se Bar-Lev \& Leslau 1994.
} 
pr. familie foruden nytilkommende haredi immigranter og et vist antal nyomvendte. Paradoksalt nok demonstrerer succesen imidlertid samtidig skrøbeligheden i haredims magt. Reproduktionssystemet hviler nemlig på, at offentligheden er villig til at acceptere tre ting:

1) Udskydelse af aftjening af værnepligt så længe de unge haredim forbliver under uddannelse. Under den nuværende ordning kan den unge forblive i yeshivah/kollel indtil han er 41 år, hvorefter han fritages helt for værnepligt (har han fem børn, bliver han det allerede ved 35 år). Mange forbliver imidlertid i kollelen i mange år derefter. Denne ordning vil et stort flertal af israelere ikke mere acceptere; og hvad værre er, Højesteret vil heller ikke, fordi det kolliderer med lighedsprincippet. Knesset blev ved en højesteretskendelse fra 1998 tvunget til at nedsætte et udvalg, der er kommet med forslag til en nyordning gående ud på, at de unge kan forlade haredi uddannelsessystemet i 23 års alderen i et år, hvor de finder ud af, om de ønsker at fortsætte her eller foretrækker at begynde at arbejde eller evt. få en erhvervsuddannelse. Vælger de en af disse 'sekulære' muligheder, vil de blive indkaldt til en kort militærtjeneste eller en ligeledes kort alternativ national tjenestetid (Haarets, 16/3-00). Betænkningen er endnu ikke omsat til et lovforslag, men der er klare tegn på, at flertallet af haredims rabbinere vil acceptere det i betragtning af det fattigdomsproblem, den eksisterende praksis har skabt blandt haredim. Forslaget løser ikke lighedsproblemet, men vil utvivlsomt få mange unge haredim til at forlade deres kolleler og komme ud på arbejdsmarkedet.

2) Udgifterne til haredims skolesystemer er blevet så store, at befolkningen i almindelighed er ved at føle det som en byrde, og de er bevidste om, at de vil vokse kraftigt p.g.a. den hurtige befolkningstilvækst blandt haredim. En kollel studerende med seks børn modtager netto 6.500 NIS (ca. 10.500 kr.) i offentlige tilskud pr. måned og gennemsnitlig består 70\% af familieindkomsterne af tilskud (Ilan 1998; Berman 1998, 11 15). Trods det lever mange haredi familier under den officielle fattigdomsgrænse.

3) P.g.a. den stedmoderlige behandling af sekulære fag i haredi skoler må de fleste haredim stille sig tilfreds med lavtlønsjob, når de endelig forlader kollel'en. Og offentligheden er ikke villig til at acceptere, at staten finansierer skoler, der ikke forbereder eleverne på en tilværelse i en moderne stat og ikke gør dem i stand til at forsørge sig selv på et rimeligt niveau. Undervisningsministeriet har indtil nu valgt at se bort fra, at dets egne cirkulærer ikke overholdes i haredi sektoren. Men også her foreligger der nu en Højesteretsafgørelse (jan. 2000), der formodentligt på længere sigt vil føre til ændringer. Den siger, at 75\% af pensum i alle skoler, der oppebærer fuld støtte, skal udgøres af almindelige skolefag (Haarets, 24/1; 23/2-00).

Denne skrøbelighed betyder, at haredim har måttet bruge deres politiske magt primært til at sikre deres institutioner og har derfor været nødt til at slække på kravene om religiøst baserede ordninger for samfundet som helhed. Og fremover vil de to retskendelser gradvist komme til at betyde en højere grad af økonomisk integration af haredim. Deres stærkere involvering på alle områder af det politiske liv siden 1977 betød politisk integration, men samtidig, fordi det lykkedes dem at opnå store bevillinger til deres 
særinstitutioner, førte det til, at færre haredim kom ud på arbejdspladserne og lærte det store samfund at kende. ${ }^{41}$ Nu vendes udviklingen tilsyneladende. Det betyder dog ikke uden videre social integration; haredim vil blive ved med at søge at isolere sig for at undgå skadelig indflydelse fra moderniteten. Men det større kendskab til det israelske samfund, det øgede antal kontakter med andre israelske grupper og et revideret skolepensum vil formodentlig alligevel have sin effekt i form af holdningsændringer blandt haredim. Det er værd at bemærke, at anglo-saksiske haredim, der er emigrerede til Israel, selv ønsker flere sekulære studier i deres børns skoler, og at de i det hele taget er mere moderate end israelsk fødte haredim. De har en stærkere identifikation med den israelske stat, bedre kontakter med ikke-haredim, og større villighed til at indgå kompromiser med dem (Levi 1990, 9-20).

2. Shas som politisk parti og som revitaliseringsbevægelse

Shas er ikke blot et politisk parti, men også en vækkelsesbevægelse. Under valgkampe er det ofte svært at skelne mellem, om et møde er et valg- eller et vækkelsesmøde. Den befolkningsgruppe, som vækkelseskampagnen særligt appellerer til, består af mennesker, der lever relativt traditionelt om end ikke efter ortodokse standarder, og som kun er relativt overfladisk påvirkede af moderniteten. De har kun en vag fornemmelse for legitimiteten i normdiskussionen, da de mener, at et sæt af traditionelle værdier står indlysende fast som noget, der bør præge det offentlige liv. I øvrigt er også deres forståelse for, hvad videnskabernes udvikling betyder verdensanskuelsesmæssigt, vag. Valfart til helligmandsgrave opfattes som helbredende og velsignelsesbringende (Paludan 1993). I valgkampe bruges med effekt amuletter, helligmænds velsignelser eller forevisning af videofilm, der viser uddrivelse af en $d y b b u k,{ }^{42}$ et fænomen, der uden videre opfattes som bevis på, at der er liv efter døden og dermed, at der er en gud osv. ${ }^{43}$ En sådan dybbuk-uddrivelse gennemførtes under valgkampen i 1999 i Dimona, en udviklingsby i Negev med sefardisk flertal, af rabbiner David Batsri, hvis bedstefader har skrevet en manual til sådanne lejligheder. Begivenheden tiltrak mange mennesker (Haarets E. 30/4-99), og kasette- og videooptagelser af seancen fik stor udbredelse. Shas har senere systematisk anvendt videoen ved sine vækkelsesmøder. ${ }^{44}$

\footnotetext{
${ }^{41}$ Ravitzky (1996, 162-80) mener, formodentligt med rette, at haredims politiske involvering og dens resultater har skabt en følelse hos dem af at høre hjemme i staten, et fænomen, der står i et spændingsforhold til det element i deres teologi der siger, at de også i Israel er i galut (eksil), endog "den mest bitre galut” (R. Shakh, Mikh. I, 25).

${ }^{42}$ En afdøds ånd, der ikke finder sit blivende sted i himmelen, og derfor vender tilbage og tager bolig i et levende menneske.

${ }^{43}$ Dayan 1999, 347, fremhæver betydningen af disse sefardisk folkereligiøse elementer for Shas' succes.

${ }^{44}$ Se Bar-Moha 1999, 20, der også kan berette, at mediet Yehudit Sigauker senere - skuffet over ikke at have fået sin andel af indtægterne ved salget af videoen - hævdede, at det hele var iscenesat. Hun havde ganske vist haft depressive tilstande efter sin mands død og i drømme hørt ham tale til sig, men det var på den anden side først Shas’ rabbinere, der overbeviste hende om, at der var tale om en dybbuk, og hun havde selv under uddrivelsesceremonien fordrejet sin stemme, så hun talte med hans røst.
} 
Nogle i denne gruppe omvender sig og begynder at leve efter ortodokse standarder i afstandtagen fra, hvad de ser som modernitetens truende opløsning af normerne, en reaktion, der utvivlsomt også hænger sammen med, at vi fortrinsvis finder denne gruppe i såkaldte udviklingsbyer med hovedsagelig sefardisk befolkning med et lavere økonomisk niveau end landsgennemsnittet og med en højere arbejdsløshed eller i fattigere sefardiske kvarterer i de større byer - de samme sociale grupper, hvorfra fundamentalistiske bevægelser i Mellemøsten henter en stor del af deres tilhængere. Social og økonomisk usikkerhed eller frygt for ydre fjender øger behovet for et fast forankret og stramt normsæt, der gør tilværelsen mere overskuelig og forudsigelig (Inglehart 1997, 36-38). En anden del af denne gruppe ændrer ikke deres livsform, men sympatiserer med Shas og stemmer på partiet.

Hvor stort omfanget af omvendelser til en sefardisk haredi livsstil er, er vanskeligt at bedømme. Men fænomenet falder i øjnene. Man ser flere og flere israelere i den karakteristiske Shas beklædning (sml. Willis 1995, 137). En sefardisk domineret udviklingsby som Bet Shan har formelig gennemgået en "Shas-haredisering” (Ben-Simon 1999). Den er et ekstremt eksempel, men i det mindste en tendens i samme retning ses også i andre udviklingsbyer, og den er muligvis en af grundene til nedgangen i antallet af unge, der indkaldes til værnepligt (Haarets 23/3-00).

Shas har også været i stand til at sørge materielt for ikke så få af sine tilhængere ved ansættelser i sit skolevæsen og gennem politiske udnævnelser i funktioner under de ministerier og byrådsafdelinger, partiet har haft kontrol over. Det har derudover kunnet levere en række tjenesteydelser: børnehaver, hjem for børn fra kriseramte familier, skoler med lang skoledag, fri skolebus og varmt måltid, kulturcentre og en bred vifte af sociale hjælpeydelser (Dayan 1999, 352). Samme fremgangsmåde er almindelig hos islamiske fundamentalistiske bevægelser i Mellemøsten. ${ }^{45}$ Shas kan blot operere mere effektivt på disse områder, fordi det gennem sin regeringsdeltagelse har fået offentlige midler til rådighed til formålet.

\section{Etnicitet og religion}

Der findes også en anden og større gruppe, der er med til at give de religiøse partier, og særligt Shas, magt. Sagen er nemlig, at der ikke blot findes de to kolliderende diskurser, haredims fundamentalistiske og den diskurs, der er præget af universalistiske (menneskerets- eller demokratiske) værdier. Sidstnævnte er flettet sammen med en tredie, etnisk-national diskurs. Den diskurs, der er præget af demokratiske værdier, er universalistisk, fordi den er orienteret ud fra individet, den er diskuterende og søger ved at give grunde at stifte en indforståethed (dvs. er rationel). Den etnisk-nationale diskurs er derimod partikularistisk, orienteret ud fra kollektivet, folket, og selv om man kan beskrive dens argumentationsformer, dvs. de regler, vi kan se, sådanne argumentationer følge, som en form for rationalitet, så hviler denne diskurs i sidste instans på et irrationelt forhold: den etniske identifikation og appellen til den. Disse to diskurser kolliderer,

\footnotetext{
${ }^{45}$ Vedr. muslimske fundamentalister i selve Israel, se Israeli 1993, 130-38; på Vestbredden og i Gaza, se Abu-Amr 1994, 87.
} 
deres forskellighed til trods, ikke nødvendigvis med hinanden, men de kan gøre det, først og fremmest i spørgsmål vedrørende forholdet til Israels arabiske minoritet. Problemet er en variant af det spændingsforhold, der findes i alle liberale nationalstater mellem deres partikularistiske (nationale) og universalistiske (demokratiske) legitimation (Cohen 1995, 204).

Det var karakteristisk for jødedommen før oplysningstiden, at religion og etnisk identitet var tæt forbundne i den forstand, at hvad vi hos andre ville kalde etniske skikke her for en stor dels vedkommende blev forstået som mitsvot, dvs. som guddommeligt forordnede adfærdsformer. I de sidste par århundreder lever derimod væsentlige dele af jødedommen videre i vide kredse som blot etnisk kultur uden nogen forankring i en transcendental instans. Således holder mange, der ville svare 'nej' eller 'ved ikke' til et spørgsmål, om de tror på Gud, alligevel Sabbat og andre jødiske fester, om end med et reduceret ritual. De benytter traditionelle overgangsritualer, og jødisk historie spiller en væsentlig rolle for deres selvforståelse. På engelsk bruges de to ord Judaism og Jewishness om henholdsvis jødedommen som religion og jødedom som kultur eller etnicitet. Forskellen mellem de to begreber udtrykkes præcist af Liebman og Susser:

Jewishness, therefore, connotes a secular identity - even though many of its sources and practices may overlap with those of Judaism. Wanting to preserve powerful and immediate ties to the Jewish people and to Jewish history, many Jews turn to the Jewish heritage, to the practices contained in the Jewish religious tradition, and adopt them as their own ... In this way, religion is transformed into folkways, theology into cohesivenessenhancing family observances, and orthodox devotion into communal solidarity (Liebman \& Susser 1997, 213).

Andetsteds formulerer Susser det således:

Whether or not one is 'religious' in the familiar sense of the term, these practices and beliefs are perceived as among the defining marks of Israeli national belonging. They are identity-performances rather than truly religious observances. In other words, they are performed in the context of national self-identification with Israel and the Jewish people rather than as theologically ordained commandments (Susser 1997, 168).

Liebman og Susser fremsætter disse bemærkninger i kommentarer til den såkaldte Guttmann Rapport, den hidtil mest omfattende sociologiske undersøgelse af, hvilken rolle religion spiller for den jødiske majoritetsbefolkning i Israel. ${ }^{46}$ De konkluderer ud fra rapporten, at den israelske befolkning i henseende til adfærd fordeler sig på tre grupper: I den ene ende af skalaen ca. 20\%, der kan karakteriseres som ortodokse (inklusive såvel haredim som moderne ortodokse) og i den anden ende adfærdsmæssigt sekulære

\footnotetext{
${ }^{46}$ Liebman \& Katz 1997 er en engelsksproget sammenfatning af rapporten med tillæg af en række væsentlige indlæg i diskussionen om den. Selv om undersøgelsen er den hidtil mest omfattende, er resultaterne ikke overraskende set på baggrund af tidligere undersøgelser. En sammenfatning af en række af disse undersøgelser findes hos Kedem 1991.
} 
(ca. 10\%), personer, for hvem jødisk identifikation og adfærdsformer, der svarer til de traditionelle jødiske, er trængt stærkt tilbage af forbrugskultur, international ungdomskultur eller post-zionisme, dvs. den opfattelse, at staten er multikulturel og kun kan være en "stat for alle sine borgere”, inklusive de arabiske, ved at nedtone det etnisk jødiske præg og centrere sig om dens universalistiske, demokratiske værdier. Imellem disse to grupper befinder den tredie og største sig (ca. 70\%), som man i Israel kalder "traditionelle”. 47

Undersøgelsens trosskala viser, at lidt under 40\% enten ikke tror på Gud eller er i tvivl, om der findes en Gud. Blandt denne gruppe rapporterer således hovedparten, at de ikke desto mindre holder de jødiske fester, bruger de traditionelle overgangsritualer, holder en vis grad af kosher køkken m.v. Grunden er, at disse ting hører med til jødisk etnisk kultur og er markører for den etniske identitet.

Noget lignende er tilfældet hos en meget stor del af de "traditionelle”, der tror på Gud. For dem kan de overleverede etniske skikke blot også blive til et religiøst sprog, som de anvender som udtryk for deres religiøse følelser, fordi det nu engang er det religiøse sprog, de kender. Mange i den “traditionelle” gruppe deler også andre af de religiøse ideer end gudstroen, f.eks. tanken om, at Torahen på en eller anden måde har en guddommelig oprindelse, men det betyder ikke, at de praktiserer ritualerne på den måde (og i det omfang), som de ortodokse gør det. Tværtimod forholder de sig selektivt og (mere eller mindre bevidst) reinterpreterende til traditionen, men accepterer samtidig, at andre gør det anderledes. Det giver dem ikke problemer - skyldfølelse eller dårlig samvittighed at holde en relativt traditionel familie-sabbat, af og til med deltagelse i morgengudstjeneste i synagogen, for så om eftermiddagen at starte bilen og køre til stranden, fodboldkamp eller anden underholdning i strid med det mest centrale sabbatsbud: budet om sabbatshvilen. Man kan sige, at de står nærmere reform-bevægelsen; alligevel vil de, hvis de gør brug af de religiøse ritualer, foretrække en ortodoks gudstjeneste eller ortodokse overgangsritualer, fordi disse giver dem en følelse af jødisk kontinuitet, dvs. bekræfter den etniske identitet netop ved, at det er de ortodokse ritualer, der har gennemgået færrest ændringer i de sidste par hundrede år. Man finder sådanne "traditionelle" holdninger og adfærdsformer i en ganske stor del af befolkningen, men mest blandt sefardere.

Efterhånden som fredsprocessen er skredet fremad, er diskussionen i Israel om, i hvilket omfang og i hvilken forstand staten skal have et jødisk præg, blevet mere intens alt imens "status quo" langsomt skrider til sekularitetens fordel. ${ }^{48}$ Samtidig gør de sekulære i dag deres krav langt stærkere gældende, end de før har gjort, bl.a. som reaktion på den magtposition, de religiøse partier har haft siden 1977. Mange “traditionelle” opfatter situationen på den måde, at hvis de religiøst inspirerede ordninger i staten reduceres,

\footnotetext{
${ }^{47}$ I gruppen ”traditionelle” er der en tendens i retning af sekularisering i den forstand, at generationsskifte betyder, at færre traditionelle skikke praktiseres (Ben-Rafael \& Sharot 1991, 94; Liebman \& Katz 1997, 3).

48 "Status quo" balancen har, navnet til trods, været i bevægelse til den ene eller den anden side i hele statens historie (Don-Yehiya 1986, 208-12).
} 
så udvandes dens etniske særpræg og dermed deres egen etniske identitet. ${ }^{49}$ Problemet hidrører i sidste instans fra, at etnisk identitet og religion indtil nyeste tid altid har været tæt forbundet. Mange "traditionelle” vælgere reagerer politisk på det, de opfatter som en trussel mod deres (etnisk) jødiske identitet, ved at støtte partier, for hvem kontinuiteten mellem staten og jødisk historie er betydningsfuld, dvs. ved at støtte enten Likud eller religiøse partier. Likud er ganske vist et sekulært parti, men som nationalistisk parti tillægger det den etniske identitet og jødisk kontinuitet større betydning end Arbejderpartiet, og har derfor også haft lettere ved at samarbejde med de religiøse partier, end Arbejderpartiet har haft. Men hvis Likud svigter disse vælgere på andre områder, reagerer de ved at støtte religiøse partier i stedet. Og den socialt set dårligere stillede sefardiske befolkning i udviklingsbyerne og de større byers slumkvarterer er i stigende grad skeptiske over for Likud, fordi de finder, at partiet ikke har gjort nok for dem, og under regeringen Netanyahu endog har forværret deres situation gennem en Margareth Thatcher-agtig økonomisk politik, der har skabt større arbejdsløshed netop i denne del af befolkningen (Dayan 1999, 343). Shas derimod har foruden sit religiøse budskab et populistisk socialt program og kan tilmed hævde at repræsentere netop sefardiske vælgere.

Vi kan ikke her gå nærmere ind på det forhold, at Shas også får støtte, fordi mange i den sefardiske befolkningsgruppe er af den opfattelse, at de efter de store sefardiske indvandringer i de første årtier af statens historie blev udsat for diskrimination fra det sekulære, ashkenaziske establishments side. Om det er rigtigt afhænger ikke mindst af definitionen af begrebet “diskrimination” (Ben-Rafael \& Sharot 1991, 197-203). Men klart er det, at der blev set ned på deres kultur, og at det blev taget for givet, at de måtte lade sig assimilere til den vestligt prægede ashkenaziske kultur. Shas har vidst at spille på diskriminationsfølelsen. Partiet lod således efter korruptionsdommen over dets leder, Aryeh Deri, kort før 1999 valget udarbejde en videofilm med titlen Ani Maashim: "Jeg anklager”. Titlen var hentet fra Emile Zolas åbne brev: “J’Accuse ...!” fra 1898 i anledning af spionagedommen over den fransk-jødiske officer Alfred Dreyfus, et justitsmord, hvori antisemitisme spillede en væsentlig rolle, og hvis sagsforløb i øvrigt havde givet anledning til, at Theodor Herzl indkaldte den første zionistiske verdenskongres i 1897. Videoen blev bredt distribueret og havde som et af sine væsentligste temaer, at det ikke blot var Deri, dommen var rettet mod, men hele det sefardiske samfund i Israel. Tydeligvis havde denne form for valgkamp en positiv effekt for Shas. ${ }^{50}$

Den nye valglov, der var trådt i kraft ved valget i 1996, fremmer også de religiøse partiers interesser, selv om det modsatte var tilsigtet (Don-Yehiya 1998, 89-91). Vælgeren har nu to stemmer: Med den ene stemmer han på en statsministerkandidat og tilken-

\footnotetext{
${ }^{49}$ Betydningen af problemerne omkring jødisk identitet for udfaldet af valgkampen i 1996 behandles fyldigt i Arian \& Shamir 1999.

${ }^{50}$ Også i valgkampen 1992 udsendte Shas en video, som skulle vise, at politiundersøgelserne mod Deri i virkeligheden var rettet imod alle Torah-tro sefardere. Willis 1995, 124, citerer følgende passage fra den: ”It is not a War against Deri, it is against you. If you are Sephardic and Jewish and believe in the mitzvot and the Torah ... if you believe in Torah schools and ritual baths, it is against you.”
} 
degiver dermed, hvilken overordnet politik, han støtter. Med den anden stemmer han på et politisk partis Knessetliste. Fordi han har stemt på en statsministerkandidat, kan han nu friere udnytte den anden stemme til at søge særlige, f.eks. religiøse eller gruppemæssige (sefardiske), interesser plejet. Og det gør vælgerne i rigt mål.

Shas får altså magt p.g.a. et kompleks af etniske og sociale faktorer. Men af samme grund er dets magt på det religiøse område - til at forskyde "status quo" i religiøs retning - begrænset: Går partiet videre end til at søge nogenlunde at bevare "status quo", vil mange af dets traditionelle vælgere, der for en stor dels vedkommende er tilfredse med den eksisterende "status quo", falde fra.

\section{Konklusion}

Et af de mest karakteristiske forhold ved haredims politiske holdninger er, at de ikke er rede til at tage konsekvenserne af det, R. Shakh så præcist formulerer: "Israel er en stat, bygget på [sekulær] lov, og ikke på halakhah” (Mikh. I, 6; 22). Gedolim kan således offentliggøre et opråb, der fastslår, at eftersom Torahen er guddommelig og uforanderlig, "må det være aldeles utænkeligt, at nogen instans, regeringsmæssig, administrativ eller retslig, blander sig på nogen som helst måde i anliggender, der er forbundet med halakhah og Israels tradition" (YN 15/1; YNE 22/1-99). I sådanne anliggender er halakhah altså eneste og ubestridelige autoritet. Men, som staten nu engang er opbygget, har alle love deres kilder i sekulære autoriteter: $\mathrm{i}$ Knessets beslutninger og i domstolenes lovinterpretation. Som den tidligere justitsminister Hayyim Tsadok fremhævede efter 14/2-demonstrationen, hviler dette, at ægteskab og skilsmisse i Israel finder sted i overensstemmelse med halakhahen, alene på, at sådan har den sekulære lovgivende forsamling besluttet. Ligeledes hidrører overrabbinatets status og autoritet alene herfra - og ikke fra nogen guddommelig autoritetskilde. Hvis haredim ikke kan acceptere dette, men søger at underminere dette sekulære fundament, så er der, tilføjer han truende, intet andet at gøre, end at de sekulære bruger deres parlamentariske magt til at hindre dette forehavende: "Den mund, der forbød, kan også tillade - og omvendt.” (Yediot, 24 Shaot, 15/2-99).

Det er imidlertid ikke så meget det ikke-ortodokse flertal i Knesset, der i det seneste årti har forskudt "status quo" i sekulariserende retning. Det skyldes først og fremmest dels private, der har åbnet restauranter, kultur- og underholdningsetablissementer og butikker på helligdage, uden at myndighederne har kunnet eller villet hindre det, dels domstolenes kendelser. Haredim er blevet tvunget til at koncentrere sig om bevarelse af den eksisterende "status quo", og selv det er ikke lykkedes. YN 22/1-96 klager ikke uden grund sin nød:

Staten Israel ændrer sig mere og mere til at være en sekulær stat. Det vil være evident for enhver, der foretager en sammenligning mellem dens karakter for et årti eller to siden og det, der sker i den i dag, at der intet er blevet tilbage af hele den status quo, som har udgjort det fundament, på hvilket sekulære og religiøse har bygget deres fælles liv i den 
[staten] i de 50 år, den har eksisteret. I samme grad, som ‘den religiøse magt’ og dens repræsentation i Knesset steg, forstærkedes sekulariteten.

Det er naturligvis en overdrivelse; men tendensen er der. Og selv om haredi samfundet vokser, og Shas' evne til at tiltrække nye tilhængere og sympatisører næppe har nået sit maksimum endnu, så er skrøbelighederne i haredims magt som påvist ovenfor tydelige. Kulturkampen vil formodentlig intensiveres af den energi, som en evt. fredsslutning frisætter, men det vil blive vanskeligt for dem at bremse den gradvise udvikling i retning af en sekularisering af den offentlige sfære i Israel.

\section{Kilder}

HaRav ElieZer Menahem Man SHAKH

Mikhtavim U-Maamarim (“Breve og Taler”, fork. Mikh.), Del 1-2 (1 vol.); Del. 3, 5748 (1988/89), og Del 5, 5755 (1995/96), Bene Berak.

BeZot Ani Boteah (“Dette stoler jeg på”, fork. BeZot.), 5758 (1998/99), Bene Berak.

Aviser

De hebraisk-sprogede dagblade Yated Neeman (fork. YN) og HaModia (fork. Mod.) overvåges af hvert sit “åndelige råd” fra henholdsvis Degel HaTorah og Agudat Israel. De engelsksprogede ugeaviser af samme navn, der overvåges tilsvarende, har egen redaktion og et andet stofvalg, da de sigter på læsere i den engelsktalende diaspora eller indvandrere herfra i Israel. De genbruger dog ofte stof fra hhv. YN og Mod. De forkortes henhv. YNE og Mod.E. Anden citeret presse er sekulære aviser, med mindre det angives, at der er tale om en haredi publikation.

\section{Litteratur}

ABU-AMR, ZIAD

1994 Islamic Fundamentalism in the West Bank and Gaza. Muslim Brotherhood and Islamic Jihad, Bloomington.

AJATOLLAH CHOMEINI

1983 Der islamische Staat, Berlin.

ARIAN, ASHER \& MiCHAL SHAMIR

1999 The Elections in Israel 1996, Albany.

BARAK, AHARON

1998 "The Role of the Supreme Court in a Democracy”, Israel Studies, 3, 2, Bloomington, 628.

Bar-Lev, Mordekhai \& Avraham Leslau

1994 The Religious World of Graduates of the Public-Religious School System (hebr.), Ramat Gan.

BAR-MoHA, YosI

1999 “Dibbuk’en: Forestillingen”, Haarets, Musaf 24/12 (hebr.), 18-22.

BEN-RAFAEL, ELIEZER \& STEPHEN SHAROT

1991 Ethnicity, Religion and Class in Israeli Society, Cambridge.

BEN-SIMON, DANIEL

1999 “Netop som vores magt er blevet styrket, kommer Satan og vækker vrede” (hebr.), Haarets 24/9, B2.

BERMAN, ELI

1998 Sect, Subsidy and Sacrifice: An Economist's View of Ultra-Orthodox Jews, Jerusalem. 
COHEN, ERIC

1995 "Israel as a Post-Zionist Society”, Wistrich, Robert \& David Ohana, eds., The Shaping of Israeli Identity: Myth, Memory and Trauma, London, 203-14.

DAYAN, ARYE

1999 The Story of Shas (hebr.), Jerusalem.

DON-YEHIYA, ELIEZER

1986 “The Resolution of Religious Conflicts in Israel”, Comparative Jewish Politics, 2, 2, Bar Ilan University, 203-18.

1998 "Religion, Ethnicity and Electoral Reform: The Religious Parties and the 1996 Elections”, i Elazar, Daniel J. \& Samuel Sandler, Israel at the Pools, London, 73-102.

FRIEDMAN, MENACHEM

1986 “Haredim Confront the Modern City”, Studies in Contemporary Jewry, 2, Bloomington, 74-96.

1987 "Life Tradition and Book Tradition in the Development of Ultraorthodox Judaism”, Goldberg, Harvey E., ed., Judaism Viewed From Within and From Without, Albany, 23555.

1991 The Haredi (Ultra-Orthodox) Society - Sources, Trends and Processes (hebr.), Jerusalem.

GOLDBERG, GIORA

1998 "Religious Zionism and the Framing of a Constitution for Israel”, Israel Studies 3, 1, Bloomington, 211-29.

HABERMAS, JÜRGEN

1982 Zur Logik der Sozialwissenschaften, Frankfurt am Main.

HEILMAN, SAMUEL

1992 Defenders of the Faith. Inside Ultra-Orthodox Jewry, New York.

Heilman, SAmuel C. \& MENACHEM FRIEDMAN

1991 "Religious Fundamentalism and Religious Jews: The Case of the Haredim”, Marty, Martin E. \& R. Scott Appleby, eds., Fundamentalisms Observed, Chicago, 197-264.

ILAN, SHAHAR

1998 “Kollel studentens kurv: 17.000 Shekel brutto”, Haarets 2/3 (hebr.), 1998.

INGLEHART, RONALD

1997 Modernization and Postmodernization. Cultural, Economic and Political Change in 43 Societies, Princeton.

ISRAELI, RAPHAEL

1993 Muslim Fundamentalism in Israel, London.

KEDEM, PERI

1991 “Dimensions of Jewish Religiosity in Israel”, Sobel, Zvi \& Benjamin Beit-Hallahmi, eds., Tradition, Innovation, Conflict. Jewishness and Judaism in Contemporary Israel, Albany, 251-72.

LEVI, AMNON

1990 "Anglo-Saxon Haredim. Can they serve as a Bridge between Haredim and Nonreligious?”, Liebman, Charles S., ed., Religious and Secular. Conflict and Accomodation between Jews in Israel, Jerusalem, 1-20.

LIEBMAN, CHARLES S.

1993 “Attitudes Toward Democracy Among Israeli Religious Leaders”, Kaufman, Edy, Shukri B. Abed \& Robert L. Rothstein, eds., Democracy, Peace, and the Israeli-Palestinian Conflict, Boulder, 135-61.

1997 Religion, Democracy and Israeli Society, Amsterdam.

LIEBMAN, CHARLES S. \& EliHU Katz 
1997 The Jewishness of Israelis, Albany.

LieBMAN, CHARLES S. \& BERNARD SUSSER

1997 “The Forgotten Center: Traditional Jewishness in Israel”, Modern Judaism, 17, 2, Baltimore, 211-20.

Paludan, Peter SteEnsgaArd

1993 “Immigranter fra en anden verden”, Religion 1993, 2, 10-19 og 3, 34.

1995 “Yated Neeman og israelsk politik”, Nordisk Judaistik 16, Aarhus, 1-24.

Peres, Yochanan \& EPHRAim YuCHTMAN-YAaR

1998 Fra konsensus til strid - Demokrati, sikkerhed og fred i den israelske bevidsthed (hebr.), Jerusalem.

QUTB, SAYYID

1978 Milestones, Beirut and Damascus.

RAVITZKY, AVIEZER

1996 Messianism, Zionism and Jewish Religious Radicalism, Chicago.

ROTH, SOL

1988 Halakhah and Politics. The Jewish Idea of the State. New York.

SCHWEID, ELIEZER

1994 Democracy and Halakhah, Lanham.

SHARKANSKY, IRA

1996 Rituals of Conflict. Religion, Politics, and Public Policy in Israel, Boulder.

SHAROT, STEPHEN

1992 "Religious Fundamentalism: Neo-traditionalism in Modern Societies”, Wilson, Bryan, ed., Religion: Contemporary Issues, London, 24-45; 259-64.

STILLMAN, NORMAN A.

1995 Sephardi Religious Responses to Modernity, Luxembourg.

SUSSER, BERNARD

1997 “Comments on the Guttmann Report”, Liebman, Charles S. \& Elihu Katz, eds., The Jewishness of Israelis, Albany, 166-71.

WILLIS, AARON P.

1995 "Shas - the Sephardic Torah Guardians. Religious 'Movement' and Political Power", Arian, Asher \& Michal Shamir, eds., The Elections in Israel 1992, Albany, 121-39.

ZUCKER, NORMAN L.

1973 The Coming Crisis in Israel. Private Faith and Public Policy, Cambridge Mass.

\section{Summary}

This study - Jewish Fundamentalism in Israel and Democracy - examines the political concepts and practice of the haredi (ultra-orthodox) political parties, Shas and United Torah Judaism. It tries to establish their traditionalist concept of legitimate political power and its distinctions compared to modern concepts. Basing itself to a large extent on the writings of Rabbi Eliezer Menahem Shahk and the "Lithuanian" haredi daily Yated Neeman, the article investigates the haredi understanding of freedom and democracy versus traditional Jewish law (halakhah), focusing on both haredi theoretical explanations of the concepts and on their actual political practice. It especially examines the haredi attitudes as regards three subjects: issues concerning a possible Israeli constitution, basic laws, and the function of the high court as a constitutional court. Hereby the differences between the haredi understanding and use of the term democracy and the modern liberal concept are pointed out. The last part of the article focuses on the electoral basis of haredi power, the growth of haredi communities by natural population increase, new haredi immigrants, new returnees to tradition, and the 
ability of in particular Shas to enlist voters from traditional (but non-orthodox) economically weak Sephardic circles. The article points to weaknesses in this power base which could in the future create problems for the haredi parties in their attempt to preserve the "status quo", the balance between secular and religious in Israeli public life.

Peter Steensgaard Paludan Lektor i judaistik, cand.theol. Institut for Religionsvidenskab Aarhus Universitet 